\title{
Assessing the effect of radioactive waste glass dissolution on early-stage radionuclide migration using simplified geological repository Monte Carlo transport models
}

\author{
Joseph N. P. Lillington ${ }^{1} \cdot$ Thomas L. Goût $^{1} \cdot$ Mike T. Harrison $^{2} \cdot$ Tajudeen M. Iwalewa $^{3} \cdot$ Ian Farnan $^{1}$
}

Received: 22 November 2020 / Accepted: 13 January 2021 / Published online: 28 January 2021

(c) The Author(s) 2021

\begin{abstract}
The vitrification of radioactive waste within glass and subsequent disposal within a geological disposal facility (GDF) requires a comprehensive understanding of the effect of glass dissolution on GDF performance. This paper aims to analyse the effect of both high-level and intermediate-level waste (HLW and ILW) glass dissolution source terms on radionuclide release into the geosphere just above the disposal vault (the 'crown'). Radionuclide migration was simulated in GoldSim for HLW in either granite or clay host rocks with a bentonite buffer using carbon steel or copper canisters, whereas ILW simulations considered either granite or clay host rocks, in either bentonite buffer or cement backfill, using concrete or cast-iron canisters. Glass dissolution source terms were varied by coupling GoldSim and MATLAB to modify the initial, residual, and resumption dissolution rates of the glass or by applying the analytical GRAAL model to glass dissolution. HLW glass results indicate no preference of granite over clay host rocks for a given canister type but that a copper canister is preferable to steel. ILW results suggest that a granite-bentonite-cast-iron environment yields lowest crown activities with cast-iron preferable to concrete as the canister, bentonite preferable to cement as the buffer/backfill, and granite preferable to clay as the host rock. Varying glass dissolution source terms (initial, residual, and resumption dissolution rates) had an understood effect on radionuclide migration, although changes were arguably insignificant considering peak crown activity for both HLW and ILW.
\end{abstract}

Keywords Glasses $\cdot$ Modelling $\cdot$ Disposal $\cdot$ Migration $\cdot$ Radionuclides

\section{Introduction}

The UK ultimately intends to dispose of its intermediate and high-level waste (ILW and HLW, respectively) within a geological disposal facility (GDF), a highly engineered, complex structure designed to dispose of radioactive waste

Supplementary information The online version of this article (https://doi.org/10.1557/s43580-021-00009-0) contains

supplementary material, which is available to authorized users.

Joseph N. P. Lillington

jnp12@cam.ac.uk

1 Department of Earth Sciences, University of Cambridge, Downing Street, Cambridge CB2 3EQ, UK

2 National Nuclear Laboratory, Central Laboratory, Sellafield, Seascale, Cumbria CA20 1PG, UK

3 John A. Paulson School of Engineering and Applied Sciences, Harvard University, 29 Oxford Street, Cambridge, MA 02138, USA deep underground, thereby limiting radionuclide migration to the biosphere through a series of constructed and natural barriers [1]. The HLW is vitrified into a borosilicate glass matrix, in part due to the high durability and significant reduction in waste volume, and more recently, intermediatelevel waste (ILW) has also been considered as suitable for vitrification [2].

Historically, whilst numerous studies have analysed the effect of glass composition or leaching conditions on glass dissolution, glass dissolution and GDF performance research have been separate with few studies integrating experiments with models. One important work [3, 4] varied glass dissolution source terms in the context of Belgium Boom Clay HLW disposal, finding only a minimal increase in peak radionuclide fluxes compared with using realistic corrosion rates. Nonetheless, there has remained a need to understand the propagation of more fully understood experimental dissolution and modelling results forward to radionuclide fates in the geosphere. This is especially important given that current UK industrial practice is to use constant HLW glass 
dissolution rates as source terms [1], and other simplistic models are employed internationally, for example, as exemplified with the two-stage $\left(V_{\mathrm{o}}-V_{\mathrm{r}}\right)$ French operational term [5]. Moreover, no UK site has yet been chosen for a GDF. Therefore, a variety of disposal conditions currently need to be implemented within GDF models. Related to this is the significant influence of leaching conditions (for example, temperature, $\mathrm{pH}$, etc.) and glass composition (for example, magnesium) on glass corrosion rates [6]. In addition, regulatory and public support will require confidence that the release of radionuclides into the geosphere will be limited despite glass dissolution variability.

With this motivation, this paper examines the effect of HLW and ILW glass dissolution source terms on the initial stages of radionuclide release from a repository vault, via simplified radionuclide transport models, using GoldSim [7]. The HLW models previously developed by Iwalewa and Farnan [8] have been extensively modified for this study. Our work is novel in that these underlying models have been substantially improved using more realistic HLW model parameters, have been adapted for ILW glass, and have had the original simplistic glass dissolution source terms varied. Importantly, few studies have analysed the impact of HLW or ILW glass dissolution on early-stage radionuclide migration from a GDF or compared the effectiveness of the various GDF components. Further information is supplied within the Supplementary Data for further background information.

\section{Methods}

There are two aspects to this paper; base-line HLW/ILW simulations have first been performed followed by assessing the effect of glass dissolution variability on these base-lines.

\section{GoldSim conceptual base-line models}

A schematic of the HLW/ILW GoldSim models is presented in Fig. 1, with detailed model information given in the Supplementary Data. The HLW scenarios consider three waste packages defined as HLW glass enclosed in either carbon steel or copper canisters placed in a disposal vault, which is surrounded by bentonite buffer at the top and on both sides. The vault is situated within a host rock (either granite or clay), sectioning the host rock into two parts (base and crown). Four scenarios have therefore been developed. In each model, groundwater at a temperature of $40^{\circ} \mathrm{C}$ flows upwards into the disposal vault leading to canister corrosion. Upon failure, the groundwater would react with the waste glass, leading to dissolution, which Iwalewa and Farnan [8] had measured directly in both granitic and sedimentary (clay) groundwaters for a UK HLW simulant Magnox waste glass of $25 \mathrm{wt} \%$ waste loading (MW25). Mobile radionuclides would diffuse into the surrounding bentonite buffers and be subsequently transported by both diffusion and advection into the crown of the host rock where radionuclide sorption also takes place.

For the eight ILW scenarios, a single waste package defined as ILW glass encased in either a cast-iron or concrete 5001 drum canister is contained within the vault, surrounded by either bentonite buffer or cement backfill in identical geometry above and to the side of (but not within) the vault, located within either a clay or granite host rock. Similar to the HLW models, up-flowing groundwater leads to canister failure and glass dissolution in time, leading to radionuclide migration from the vault to the crown via diffusion and advection, limited only by radionuclide decay, sorption, and insolubility. The modelled radionuclides were chosen based on their half-lives and initial activity per canister. The impact of organics was not considered in the baseline simulations, in part due to the uncertainty on the scaling factors and need for a direct comparison between bentonite and cement environments.

\section{Variation of HLW and ILW glass dssolution source terms}

In the original (and base-line) HLW models, simplistic HLW glass degradation rates $\left(\right.$ day $\left.^{-1}\right)$ were applied
Fig. 1 A schematic of the ILW/HLW models, adapted from Iwalewa and Farnan [8]. Groundwater flows upwards (black arrows) from the base host rock to the sink. Radionuclides are transported following glass dissolution and canister failure

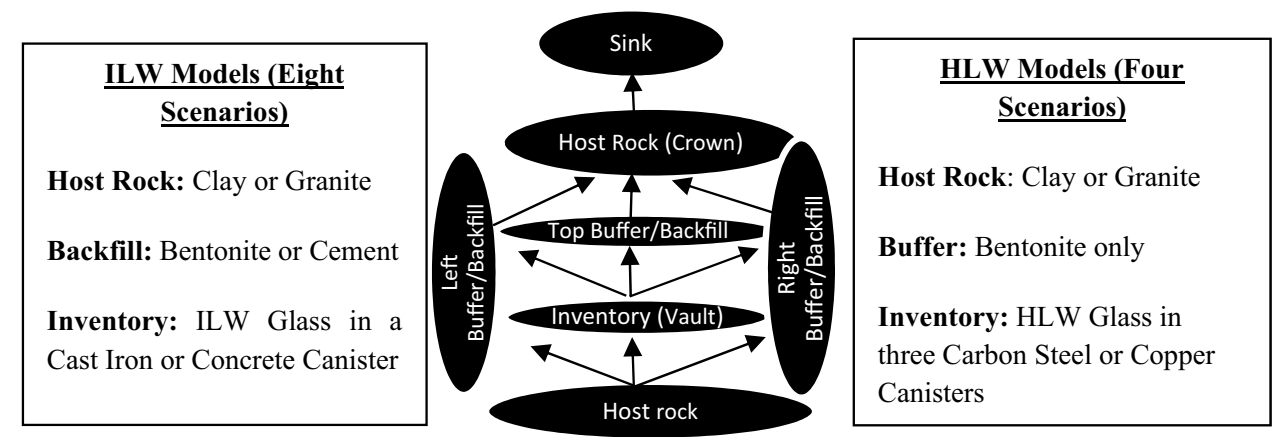


by computing the product of MW25 geometric specific surface area $\left(0.0201 \mathrm{~m}^{2} \mathrm{~g}^{-1}\right.$ for spherical glass particles of an average diameter of $112.5 \mu \mathrm{m}$ ) and a uniform rate distribution (clay: $0.12-0.16 \mathrm{~g} \mathrm{~m}^{-2} \mathrm{day}^{-1}$, granite: 0.06-0.12 $\mathrm{g} \mathrm{m}^{-2}$ day $^{-1}$ ) determined from single-pass flowthrough experiments [8]. The overall rate was held at the initial rate for up to 500 years, then decreased by a factor of 1000 emulating a residual rate for up to 500,000 years, and subsequently increased by a factor of 100 for rate resumption until the calculated glass canister mass loss reached the initial canister mass (complete dissolution). The ILW base-line models here consider an initial dissolution rate of $0.062 \pm 0.007 \mathrm{~g} \mathrm{~m}^{-2} \mathrm{day}^{-1}\left(0.0198 \mathrm{~m}^{2} \mathrm{~g}^{-1}\right)$, as measured by Mann et al. [2] on a Laboratory BoroSilicate glass (LBS), again using residual and resumption scaling factors of 1000 and 10 , respectively.

Variation on these base-line glass dissolution source terms was subsequently applied in five different ways:

1. Variation on the initial dissolution rate the residual and resumption rates were also modified through their relationship by scaling factors (1000 and 10, respectively) to the initial dissolution rate.

2. Variation on the residual dissolution rate the base-line initial dissolution rates and resumption scaling factors were held constant.

3. Variation on the resumption dissolution rate the baseline initial dissolution rates and residual rate scaling factors were held constant.

4. Use of an overall constant rate (HLW models only) this was specified by the disposal system safety case data report (Radioactive Waste Management) [1].

5. Variation on the overall glass dissolution rate: $\boldsymbol{H L W}$ models only the glass reactivity in allowance of the alteration layer (GRAAL) analytical model [9] was also used to further analyse the effect of HLW source terms on radionuclide migration. Since GRAAL has not been well parameterised for UK glasses, variation on the better known SON68 parameters was used considering substantial variation on either side of the known values. GRAAL models were subsequently run under randomised parameters (1000 iterations) in MATLAB, and these were coupled with GoldSim to perform sensitivity analysis on the effect of model parameters (and glass dissolution in general) on GDF performance. In addition, systematic variation on GRAAL model parameters (altered layer diffusion constant, surface area to leachant volume ratio, secondary phase precipitation threshold concentration, etc.) was applied to assess their effect on vault/crown cumulative activities as a function of time. The GRAAL computed fractional degradation rates $\left(\right.$ day $\left.^{-1}\right)$ were used as GoldSim source terms. The rates were set to zero after specific times once the glass had fully dissolved, computed having integrated the mass loss of glass as a function of time, thereby preventing source term dissolution beyond the complete removal of the vitrified waste. HLW and ILW models sensitivity analysis was performed having simultaneously randomly varied the initial dissolution, residual, and resumption rates.

\section{Results}

\section{Base-line results}

Figure 2 presents the total activity in the vault and crown as a function of time across the HLW and ILW base-line models. For the HLW models, crown activity was lowest when considering a copper container irrespective of host rock. For the ILW models, the granite-bentonite-cast-iron environment gave lowest cumulative crown activities over all time. Additional results are discussed in the Supplementary Data.

\section{Effect of glass dissolution source term variation}

Figure 3 shows the change in crown activity in the best performing HLW/ILW models having varied initial dissolution (IDR) and residual rates [via scaling factors (SF)].

\section{Discussion}

\section{HLW base-line models}

In the HLW base-line models, total vault activity was significantly higher than in the crown by several orders of magnitude (Fig. 2), and in both the vault and crown, cumulative activity increased between 5000 and 100,000 years after time which total activity decreased. Comparing the original models of Iwalewa and Farnan [8] and the base-lines in the vault, conservatively, the peak activity in the vault of $10^{13} \mathrm{~Bq}$ in the updated models was $4 \%$ of the initial total inventory (approximately $10^{14} \mathrm{~Bq}$ ), which was only slightly higher than in the original models (approximately 1\%). The updated model vault activities were reduced following the increase in the steel/copper canister failure rate, as expected. In contrast, updates to both the initial radionuclide activity and number of canisters caused relative increases in cumulative vault activity, see Figs. S4 and S5. The total crown activity was significantly lower in all of the updated models by approximately one to two orders of magnitude throughout time. This reduction was due to the modifications to the steel/copper canister failure rate, inventory/number of canisters, solubility and sorption in bentonite, and sorption in 
Fig. 2 The cumulative activities across the different base-line models (top: HLW, vault; row 2 : HLW, crown; row 3: ILW, vault; bottom: ILW, crown)
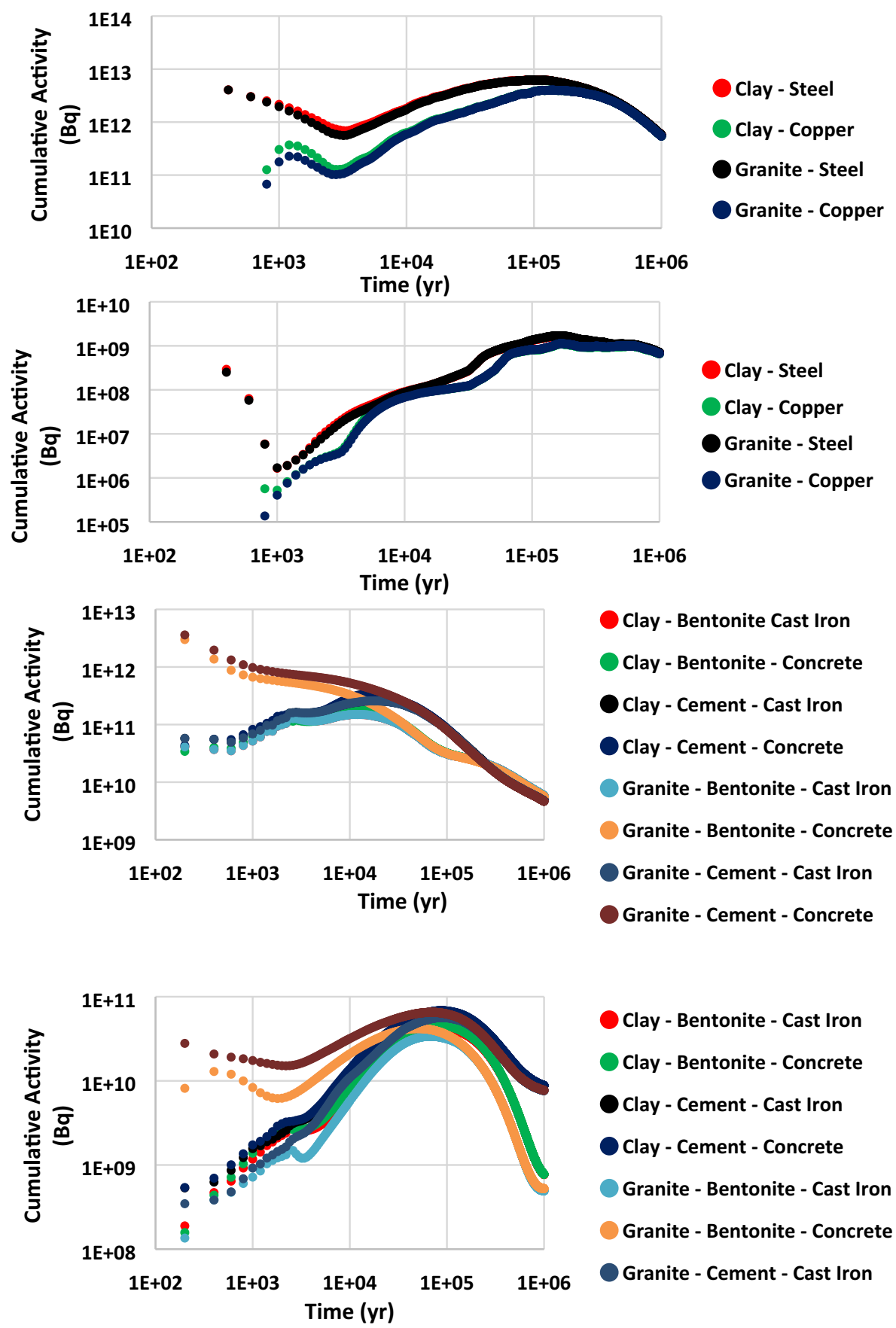

clay/granite. This is consistent with the model updates. For example, influential factors shown to cause the reduction in the crown activity are the decrease in ${ }^{79} \mathrm{Se}$ bentonite solubility, increase in ${ }^{241} \mathrm{Am},{ }^{237} \mathrm{~Np},{ }^{99} \mathrm{Tc}$, and ${ }^{239} \mathrm{Pu}$ bentonite sorption, and reduction in ${ }^{79} \mathrm{Se}$ clay sorption. See Supplementary Data for the model parameter changes.

Radionuclide activities showed similar behaviour between the original GDF models of Iwalewa and Farnan [8] and updated models across the four scenarios, despite the modifications. As examples for the vault, radionuclide activities (excluding ${ }^{239} \mathrm{Pu}$ and ${ }^{238} \mathrm{U}$ ) were only approximately $500 \mathrm{~Bq}$ higher in the updated models with short half-life isotope activities $\left({ }^{241} \mathrm{Am},{ }^{137} \mathrm{Cs},{ }^{90} \mathrm{Sr}\right)$ falling to zero at relatively short-timescales and with long half-life radionuclide $\left({ }^{99} \mathrm{Tc}\right.$, ${ }^{237} \mathrm{~Np},{ }^{79} \mathrm{Se},{ }^{238} \mathrm{U}$ ) activities typically increasing with time and then decreasing. As examples for the crown, generally, long half-life $\left({ }^{99} \mathrm{Tc},{ }^{237} \mathrm{~Np},{ }^{79} \mathrm{Se},{ }^{238} \mathrm{U}\right)$ activities increased in time with peak activities being similar, with ${ }^{79} \mathrm{Se},{ }^{99} \mathrm{Tc}$, and ${ }^{237} \mathrm{~Np}$ having highest activities at the GDF design lifetime. These results are generally corroborated by the work of other performance assessments in both clay [3] and granitic [10] environments. Nonetheless, in the original models, granite 
Fig. 3 Crown activity changes having varied glass dissolution rates (row 1: IDR HLW granite, copper, row 2: residual rate ILW granite-bentonite-castiron canister). Activities are relative to base-lines (top: IDR $0.09 \mathrm{~g} \mathrm{~m}^{-2}$ day $^{-1}$, bottom: $\mathrm{SF}$ 1000)
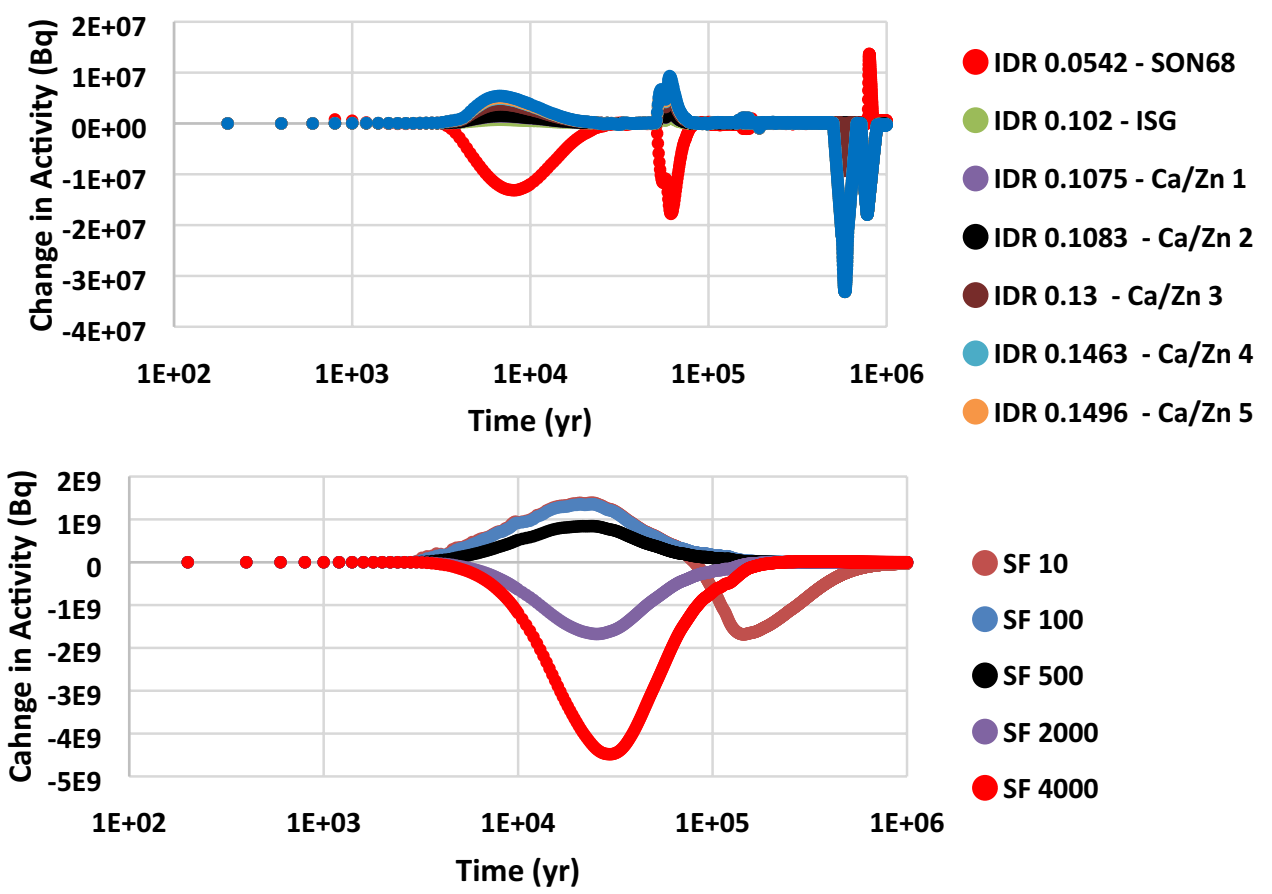

(single or dual canisters) gave smallest cumulative activities in the crown from 1000 years to the end of design lifetime. After the modifications, cumulative crown activity differences across the four scenarios were reduced with simulations now indicating that a copper canister is favourable to steel with there being no difference between using granite versus clay for a given canister type (Fig. 2). This may be influenced by the increased importance of the canister in preventing radionuclide release in the updated models.

\section{ILW base-line models}

In the ILW base-lines, activities were significantly lower (1-2 orders of magnitude) in the crown compared with the vault throughout time (Fig. 2), with vault activities showing substantial differences across the scenarios up to 10,000 years but with these differences reducing thereafter. Results show that crown cumulative activity is lowest in a granite-bentonite-cast-iron environment $\left({ }^{135} \mathrm{Cs},{ }^{59} \mathrm{Ni}\right.$ significant) and highest when using a cement backfill $\left({ }^{59} \mathrm{Ni}\right.$, ${ }^{99} \mathrm{Tc},{ }^{93} \mathrm{Zr}$ significant) with concrete canister irrespective of the host rock. This is expected as, for example, the concrete canister has a significantly shorter failure time than cast-iron (Table S6). At long times (>10 5 years), bentonite buffer was favourable to cement backfill, likely due to the lower bentonite flow rates and greater sorption coefficients. These results are largely supported by [11], whereby the peak cumulative near-field flux was order of one magnitude lower in the bentonite versus cement environment. However, some caution should still be given here due to the use of identical glass dissolution rates in the base-line simulations and the neglect of microbial effects, which would reduce radionuclide sorption and enhance solubility [11]. Figure 2 indicates that granite is favourable over clay for a given backfill and canister, and, as expected given the significantly longer canister failure time, cast-iron is favourable over a concrete container for a given host rock and backfill.

\section{Effect of glass dissolution variability}

For the HLW models, results showed no significant difference in using the original or industry standard source terms, and that independent changes to the initial dissolution, residual, and resumption rates have an understood but insignificant change on peak radionuclide activity. For example, Fig. 3 shows that as the initial dissolution rate is increased specific to different glass compositions, crown activity increases up to approximately 500,000 years but thereafter decreases relative to the base-line. This is reasonable; an increase in glass dissolution should cause faster radionuclide release from the vault and more rapid transport into the crown (yielding increased fluxes), whereas this release would be delayed (hence the latter decreased fluxes) for the base-line models. As another example, random variation on the overall glass degradation rate gave a peak crown activity of $1.3871 \mathrm{GBq}$ that was negligibly larger than the 1.3867 GBq value determined for the highest performing granite-copper base-line model. Note that having systematically varied analytical GRAAL parameters, simulations indicated that the vault and crown cumulative activities are directly correlated with the glass degradation rates, which themselves have an understood influence from the GRAAL 
model parameters (kinetic rate of passivating reactive interface dissolution, precipitation rate, etc.).

For the ILW models, results also showed that independent changes to the initial dissolution, residual, and resumption rates have an understood but small effect on peak crown activity. For example, Fig. 3 shows as the residual rate increases (scaling factor decreases) crown activity increases at shorter timescales but decreases after 100,000 years relative to the base-line. Moreover, having performed random variations on the overall rate, peak cumulative activities were not significantly different between models. As illustrated, there was a peak value of $34.224 \mathrm{GBq}$ activity across the random models relative to the base-line value of 33.874 GBq for the granite-bentonite-cast-iron model.

The small observed glass dissolution effect on peak crown activity has some support from the literature $[3,4$, $10,12-14]$. One example is taken from the Belgium disposal concept $[3,4]$, whereby radionuclide fluxes were only minimally increased having varied dissolution source terms in comparison to use of realistic glass corrosion rates. A second example is taken from the Swiss Opalinus clay case $[4,10]$, where dose rates were still four orders of magnitude below the regulatory limit having decreased the vitrified canister lifetime to 100 years. Finally, in the Finnish KBS-3 crystalline rock case $[4,13]$, under the scenario of instantaneous canister release, the maximum dose rate only slightly increased from 2.9 to $4.3 \times 10^{-5} \mathrm{mSv}$ year ${ }^{-1}$ compared with the reference. Further model development would be of value to support this study's findings. This includes direct glass dissolution—radionuclide chemistry/transport coupling, for example, to allow for interaction between glass corrosion and the near-field components [15] or broaden the model to understand the impact of glass dissolution in the far-field with respect to radionuclide dose. Other suggestions for future work are stated in the Supplementary Data.

\section{Conclusions}

This paper has analysed the effect of glass dissolution on radionuclide release, near to the repository vault, using Monte Carlo GoldSim models. HLW base-line scenarios indicate no preference in granite over clay as the host rock for a given canister but indicate that a copper canister is favourable to steel. ILW base-lines indicate that a granite-bentonite-cast-iron environment yields lowest crown activities with a cast-iron canister preferable to concrete, bentonite preferable to cement as backfill, and granite host rock preferable to clay. Variation on simplistic glass dissolution source terms (initial dissolution, residual rate, resumption rate) had a small (considering peak crown activities) but understood effect on radionuclide release for both HLW and ILW models.

Acknowledgements Funding was from an EPSRC Imperial-CambridgeOpen University Centre for Doctoral Training PhD Project (EPSRC Grant Number EP/L015900/1). The authors thank GoldSim [7] for their software and the National Nuclear Laboratory for supplying data.

Data availability Data are available upon reasonable request and in the Supplementary Data.

\section{Compliance with ethical standards}

Conflict of interest On behalf of all authors, the corresponding author states that there is no conflict of interest.

Open access This article is licensed under a Creative Commons Attribution 4.0 International License, which permits use, sharing, adaptation, distribution and reproduction in any medium or format, as long as you give appropriate credit to the original author(s) and the source, provide a link to the Creative Commons licence, and indicate if changes were made. The images or other third party material in this article are included in the article's Creative Commons licence, unless indicated otherwise in a credit line to the material. If material is not included in the article's Creative Commons licence and your intended use is not permitted by statutory regulation or exceeds the permitted use, you will need to obtain permission directly from the copyright holder. To view a copy of this licence, visit http://creativecommons.org/licenses/by/4.0/.

\section{References}

1. Radioactive Waste Management, Geological Disposal: Generic Disposal System Safety Case Data Report, 2016. https://rwm.nda.gov. uk/publication/geological-disposal-generic-disposal-system-safet y-case-data-report/. Accessed 20 March 2020

2. C. Mann, J.R. Eskelsen, D.N. Leonard, E. Pierce, C.L. Corkhill, The dissolution of simulant vitrified intermediate level nuclear waste in young cement water. MRS Adv. 5, 131-140 (2020). https://doi. org/10.1557/adv.2020.40

3. D. Mallants, J. Marivoet, X. Sillen, Performance assessment of the disposal of vitrified high-level waste in a clay layer. J. Nucl. Mater. 298, 125-135 (2001). https://doi.org/10.1016/S0022-3115(01)00577 $-3$

4. D. Mallants, N. Chapman, How much does corrosion of nuclear waste matrices matter. Nat. Mater. 19, 959-961 (2020). https://doi. org/10.1038/s41563-020-0741-5

5. I. Ribet, S. Gin, N. Godon, Y. Minet, P. Jollivet, P. Frugier, É. Vernaz, J.-M. Cavedon, V. Petitjean, The $\mathrm{V}_{\mathrm{o}}-\mathrm{V}_{\mathrm{r}}$ operational model for the long-term behavior of vitrified R7T7 waste packages, in Advances for Future Nuclear Fuel Cycles Nimes, Atalante, France (2004), pp. 1-8

6. Radioactive Waste Management, Geological Disposal: Waste Package Evolution Status Report, 2016. https://rwm.nda.gov.uk/publi cation/geological-disposal-waste-package-evolution-status-report/. Accessed 24 Jan 2021

7. GoldSim, User's Guide GoldSim (2018). https://www.goldsim.com/ web/customers/education/documentation/. Accessed 16 Feb 2019

8. T.M. Iwalewa, I. Farnan, Coupling radioactive waste glass dissolution measurements in generic groundwaters with reactive transport modeling of repository scenarios. Water Resour. Res. 55, 8010-8027 (2019). https://doi.org/10.1029/2018WR024218

9. Y. Minet, B. Bonin, S. Gin, P. Frugier, Analytic implementation of the GRAAL model: application to a R7T7-type glass package in 
a geological disposal environment. J. Nucl. Mater. 404, 178-202 (2010). https://doi.org/10.1016/J.JNUCMAT.2010.07.015

10. P.E. Mariner, J.H. Lee, E.L. Hardin, F.D. Hansen, G.A. Freeze, A.S. Lord, B. Goldstein, R.H. Price, Granite Disposal of U.S. High-Level Radioactive Waste, SANDIA REPORT: SAND2011-6203 (2011)

11. M. Kelly, D. Lever, C. Wilding, D. Applegate, R. Hand, Consideration of Vitrified ILW in a Geological Disposal Facility, 2009. Reference: 8915878

12. D. Mallants, J. Marivoet, X. Sillen, P. De Preter, Performance assessment of geological disposal of high-level radioactive waste in a plastic clay formation. Mater. Res. Soc. Online Proc. (2002). https://doi. org/10.1557/PROC-713-JJ4.4
13. T. Vieno, H. Nordman, Safety Assessment of Spent Fuel Disposal in Hastholmen, Kivetty, Olkiluoto and Romuvaara TILA-99 (1999)

14. M. Van Geet, E. Weetjens, 11-Strategic choices in the Belgian Supercontainer Design and Its Treatment in a Safety Case: NEA/ RWM/R(2012)3/REV: Appendix C Workshop Papers (2012)

15. M. Repina, F. Bouyer, V. Lagneau, Reactive transport modeling of glass alteration in a fractured vitrified nuclear glass canister: from upscaling to experimental validation. J. Nucl. Mater. 528, 151869 (2020). https://doi.org/10.1016/j.jnucmat.2019.151869 